\title{
Erikoispeltokasvien, camelina, hamppu, rypsi, kumina, speltti ja tattari viljelytekniikkaopas
}

Klemola, Salla ${ }^{1}$, Nevalainen Heidi ${ }^{1}$, Ripatti Sinikka ${ }^{1}$, Suhonen Pirjo ${ }^{1}$, Korhonen Kari ${ }^{2}$

1 Savonia-ammattikorkeakoulu, Iisalmietunimi.sukunimi@savonia-amk.fi

2 Marja-ja kasvisfutuurihanke,Suonenjoki etunimi.sukunimi@suojenki.fi

EU:n tuomat tukimuutokset, tavanomaisten viljelykasvien markkinahintojen lasku ja viljelyä uhkaava yksipuolisuus pakottavat viljelijöitä miettimään vaihtoehtoja tuotannolleen. Erikoispeltokasvit voivat tuoda ratkaisuja näihin ongelmiin ja luoda uusia mahdollisuuksia suomalaisille viljelijöille.

Tämän työn tarkoituksena oli luoda viljelyopas elintarvikkeeksi soveltuvista erikoispeltokasveista. Työssä käsitellään camelinaa (Camelina sativa (L.) Crantz), hamppua (Cannabis sativa L), rypsiä (Brassica rapa), kuminaa (Carum carvi), spelttiä (Triticum spelta L) ja tattaria (Fagopyrum esculentum). Pääpaino on näiden kasvien viljelytekniikassa. Työstä löytyy kasvilajikuvauksen lisäksi myös muuta perustietoa jokaisesta kasvista sekä runsaasti käytännön viljelykokemuksia, jotka esitellään yksityiskohtaisesti havaintoesimerkkeinä.

Opas on tarkoitettu erikoispeltokasveista kiinnostuneille viljelijöille ja muille asiasta lisää tietoa haluaville. Tutkimustulosten perusteella koottu viljelyopas on julkaistu Marja- ja kasvisfutuurihankkeen verkkosivuilla osoitteessa: http://mansikka.netsor.fi/materiaali/erikoispeltokasvitviljelytekniikka.pdf

Asiasanat: viljelytekniikka, verkkojulkaisu, camelina, hamppu, rypsi, kumina, speltti, tattari 


\section{Johdanto}

Kiinnostus erikoispeltokasveja kohtaan on lisääntynyt vuosi vuodelta. EU:n tuomat tukimuutokset painostavat viljelijöitä miettimään muunlaisia tuotantomalleja. Uusilla viljelykasveilla pyritään parantamaan tilojen kannattavuutta ja lisäämään monimuotoisuutta. Erikoispeltokasvit voivat tuoda uusia mahdollisuuksia suomalaisille viljelijöille ja koko elintarvikeketjulle. Erikoispeltokasveilla tarkoitetaan peltoalassa viljeltäviä tavallisista viljelykasveista poikkeavia kasveja. Erikoiskasvit-käsitettä käytetään usein myös marjoilla, vihanneksilla, juureksilla ja koristekasveilla. (Vuorio, Soini \& Ikonen 2005, 12.). Erikoispeltokasvien viljely on vielä suhteellisen pienimuotoista Suomessa, vaikka näiden kasvien suosio on lisääntynytkin viimeisen vuosikymmenen aikana yli satakertaisesti (taulukko 1).

TAULUKKO 1. Erikoispeltokasvien viljelypinta-alojen (ha) kehitys 1995-2006 (Vuorio 2005, 13; Partala.2007;Maa- ja metsätalousministeriö 2006;Värri 2006.)

\begin{tabular}{|l|l|l|l|l|l|l|l|l|l|l|l|l|}
\hline & $\mathbf{1 9 9 5}$ & $\mathbf{1 9 9 6}$ & $\mathbf{1 9 9 7}$ & $\mathbf{1 9 9 8}$ & $\mathbf{1 9 9 9}$ & $\mathbf{2 0 0 0}$ & $\mathbf{2 0 0 1}$ & $\mathbf{2 0 0 2}$ & $\mathbf{2 0 0 3}$ & $\mathbf{2 0 0 4}$ & $\mathbf{2 0 0 5}$ & $\mathbf{2 0 0 6}$ \\
\hline hamppu(kuitu+öljy) & 0 & 0 & 0 & 0 & 0 & 0 & 121 & 48 & 37 & 48 & 56 & 172 \\
\hline camelina & 0 & 0 & 0 & 0 & 0 & 0 & 0 & 272 & 24 & 192 & 1859 & 5300 \\
\hline kuitupellava & 14 & 485 & 991 & 780 & 863 & 1095 & 402 & 202 & 99 & 67 & 57 & \\
\hline kumina & 0 & 0 & 0 & 0 & 0 & 0 & 0 & 0 & 7119 & 10344 & 13227 & 22300 \\
\hline nokkonen & 0 & 0 & 0 & 0 & 0,03 & 0,53 & 3,68 & 0,71 & 0,03 & 0,24 & 1,44 & \\
\hline ruokohelpi & 0,04 & 0 & 0 & 306 & 478 & 602 & 624 & 1453 & 2744 & 4226 & 8874 & 17200 \\
\hline siemenmausteet* & 200 & 1800 & 1900 & 1500 & 1400 & 2500 & 3600 & 5431 & 820 & 253 & 289 & \\
\hline speltti & 0 & 0 & 0 & 0 & 69 & 183 & 188 & 185 & 400 & 679 & 486 & 600 \\
\hline tattari & 36 & 502 & 397 & 469 & 475 & 454 & 433 & 478 & 548 & 723 & 864 & 611 \\
\hline öljypellava & 101 & 2087 & 2304 & 2051 & 2256 & 1371 & 1597 & 1371 & 1959 & 2030 & 1782 & \\
\hline pinta-ala yhteensä & $\mathbf{3 5 1}$ & $\mathbf{4 8 7 4}$ & $\mathbf{5 5 9 2}$ & $\mathbf{5 1 0 6}$ & $\mathbf{5 5 4 1}$ & $\mathbf{6 2 0 6}$ & $\mathbf{6 9 6 9}$ & $\mathbf{9 4 4 1}$ & $\mathbf{1 3 7 5 0}$ & $\mathbf{1 8 5 6 2}$ & $\mathbf{2 7 4 9 5}$ & $\mathbf{4 6 1 8 3}$ \\
\hline
\end{tabular}

EU:n maatalouspolitiikka sekä kansainvälisen kaupan vapautuminen ovat lisänneet viljelijöiden innostusta erikoispeltokasveihin. Viljelijät hakevat katetuotoltaan parempia viljelykasveja, sillä perinteisten viljelykasvien markkinahinnat ovat laskusuuntaisia. EU on myös alkanut tukea monivaikutteista maataloutta ja kasvien monimuotoisuutta entistä enemmän. (Vuorio ym. 2005, 7; Keskitalo 2006, 1.)

Monimuotoinen kasvintuotanto parantaa pellon ja sen ympäristön hyvinvointia ja satotasoja. Monimuotoisuus merkitsee pellossa asuvien, sieltä ravintoa hakevien tai siellä vierailevien eläin-, kasvi-, hyönteis- ja mikrobilajistojen monimuotoisuutta. Monimuotoisuus tarkoittaa myös viljelykasvien perinnöllistä ja lajistollista moninaisuutta. Peltojen mikrobien monimuotoisuus vaikuttaa maan aineiden kiertoon, rakenteeseen, kasvukykyyn, vesistöihin sekä ilmakehään pääseviin päästöihin. Monipuolinen maamikrobisto estää tehokkaasti myös sienitautien leviämistä. (Vuorio ym. 2005, 7; Palojärvi.)

Tämän tutkimuksen tavoitteena oli selvittää camelinan (Camelina sativa (L.) Crantz), hampun (Cannabis sativa L), kuminan (Carum carvi), speltin (Triticum spelta L), tattarin (Fagopyrum esculentum) ja rypsin viljelytekniikkaa sekä koostaa niistä tietopaketti Internetiin. Työhön valittiin kasveja, joita voidaan tuottaa elintarvikekäyttöön. Valintaan vaikutti myös kasvien viljelyn suosio maassamme. Työ on toteutettu yhteistyössä Marjaosaamiskeskuksen Marja- ja kasvisfutuurihankeen kanssa.

\section{Aineisto ja menetelmät}

Työhön kerättiin yleistä tietoa erikoispeltokasvien historiasta, rakenteesta, kasvurytmistä, ominaisuuksista, käyttökohteista, viljelyn laajuudesta ja EU-tuista. EU-tukitiedot ovat pääosin vuodelta 2006. Ainoastaan hampun EU-tuet päivitettiin, koska muutokset olivat suuria vuonna 2007. Viljelytekniikka- 
osiossa kerrotaan kasvin maalajivaatimuksista, esikasveista, lannoituksesta, kylvöstä, kasvinsuojelusta, sadon korjuusta ja käsittelystä sekä varastoinnista. Jokaisesta kasvista on yli 30 kirjallisuusviitettä.

Erikoispeltokasvien viljelijöiden käytännön viljelykokemuksia koottiin haastattelemalla Savon seudulla viittätoista viljelijää joko puhelimitse tai tilavierailulla marras-joulukuussa 2006 ja tammikuussa 2007. Viljelijöiltä kysyttiin heidän omista viljelytavoistaan sekä mielipiteitä kasvin viljelystä, tulevaisuudesta ja kannattavuudesta. Haastattelut purettiin mahdollisimman pian haastattelun jälkeen nauhurilta tai muistiinpanoilta. Aineistosta koottiin sähköinen PDF-muotoinen julkaisu.

\section{Tulokset ja tulosten tarkastelu}

Viljelyoppaassa kuvataan perustietoja camelina-, hamppu-, kumina-, speltti-, tattari- ja rypsikasveista: kasvien käyttö ja ominaisuudet, viljelyn laajuus, EU:n määräykset ja tuet, viljelytekniikka, luonnonmukainen viljely ja viljelykokemuksia Pohjois-Savosta.

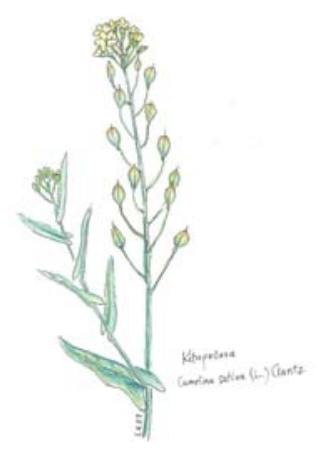

Kuva 1. Camelina (Camelina sativa (L.) Crantz)
Camelinaa (Camelina sativa (L.) Crantz) kutsutaan usein kitupellavaksi tai kansan keskuudessa ruistankioksi. Camelina ei ole nimestään huolimatta pellavakasvi, vaan yksivuotinen öljykasvi, joka kuuluu ristikukkaisten kasvien heimoon. Camelinan tuleentunut kasvusto muistuttaa kyllä pellavan kasvustoa sadonkorjuun aikoihin. Camelina voidaan kylvää keväisin ja syksyisin.

Suomen olosuhteisiin käy parhaiten kevätkylvöinen camelina, sillä syyskylvöiset lajikkeet talvehtivat huonosti. Camelina on uusvanha viljelykasvi, joka on alun perin lähtöisin Keski-Aasiasta. Euroopan alueella sitä on viljelty rauta- ja pronssikaudesta keskiajalle asti. Camelina oli pitkään unohduksissa. Kiinnostus camelinan viljelyyn lisääntyi 1980-luvulla, sillä se oli vaihtelua tuova, aikainen ja runsaasti satoa tuottava öljykasvi. Lisäksi huomattiin, että se sisälsi paljon alfalinoleenihappoja eli omega-3rasvahappoja. Käyttö uusiutuvina raaka-aineina, energianlähteinä ja terveystuotteina lisäsi kiinnostusta.

Varsinainen viljely aloitettiin Suomessa vuonna 1999. Viljelyala vaihteli alkuvuosina 200-400 hehtaaria. Camelinaa viljeltiin Suomessa 5300 hehtaarilla vuonna 2006. Viljely lisääntyi huomattavasti Raision kiinnostuessa camelinasta. (Geisler, M. 2006; Heiska, S. 2001; Muuttomaa, E.2001 Vuorio, H. ym. 2005.)

Haastatelluilla pohjoissavolaisilla viljelijöillä oli 1-2 vuoden kokemus camelinan viljelystä. Viljelypinta-alat vaihtelivat 8,5-20 ha. Camelinaa kasvatettiin karkeilla kivennäismailla ja multamailla, pH vaihteli 5,3-6,4. Camelina on kokemusten mukaan "kesähuoleton” kasvi, jolla ei ole pahoja tuholaisia tai tauteja torjuttavana. Rikkaruohojen torjunta saattaa joissakin tapauksissa lisätä kustannuksia jonkin verran. Satomäärät vaihtelivat 1200 - 1950 kg/ha. Camelinaa käytetään margariineissa, kevyttuorejuustoissa ja fraicheissa, pikapuuroissa ja levitteissä. (Liespuu, S. 2005; Joensuu, P. 2006.)

Öljyä puristettaessa syntyy siemenrouhetta. Siemenrouhetta voidaan käyttää orgaanisessa lannoituksessa. Se käy myös eläinten rehuksi, sillä camelinarouherehu parantaa kananmunien ja broilereiden rasvahappokoostumusta ja toimii hyvänä valkuais- ja energiarehuna. Siemenrouhe sisältää valkuaista jopa 35 \%. MTT on tutkinut camelinan soveltuvuutta kanoille ja tulokset ovat olleet lupaavia. Rehun huonoja puolia ovat kasvua heikentävät aineet, kuten glukosinolaatit. Vaikutuksia ei kuitenkaan ilmennyt, jos puristeen määrää rehussa rajoitetaan alle 20 \%. Tällä hetkellä EU vielä kieltää kasvin käytön eläinten rehuna. Lupaa camelinan käyttöön rehuksi on haettu ja vastauksia odotetaan. (Heiska, S. 2001; Muuttomaa, E .2001; Yhteistyön tulos. 2006; Lehtonen, S. 2006; Venäläinen, E. ym. 2006.)

USA:ssa tutkitaan camelinan hyödyntämistä ja käyttöä biodieselinä, elintarvikkeena sekä karjan ja kalojen rehuna. Camelinarehuilla pyritään nostamaan eläinten omega-3-rasvahappotasoja ja laajentamaan terveellisten elintarvikkeiden valikoimaa. Polttoainekokeet ovat antaneet hyviä tuloksia. Ongelmana on camelinan korkea jodiluku, 150-160, mikä kuvaa tyydyttymättömien rasvahappojen määrää. Mitä suurempi se on, sitä enemmän polttoainetta saattaa valua moottoriöljyn sekaan ja huonontaa viskositeettia. Tällä hetkellä camelinaa pidetään arvokkaampana elintarvikekäytössä. (Heiska,S.2001;Williams,W.2005.)

Hamppu eli Cannabis sativa L on 1-5 metriä korkea, yksivuotinen ruohomainen kasvi. Se on tuulipölytteinen, kaksikotinen ja yksineuvoinen eli hede- ja emikasvit ovat eri yksilöissä. Hamppukasvustosta noin puolet on emi- ja puolet hedeyksilöitä. On olemassa myös yksikotisia lajikkeita, joissa hede- ja emikasvi ovat samassa yksilössä. (Pahkala K. \& Virkajärvi P. 2004.) 


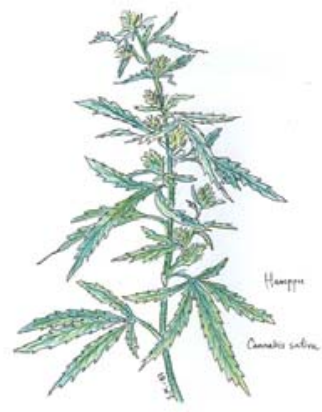

Kuva 2. Hamppu (Cannabis sativa L.)

Lyhyenpäivän kasvina tunnettua kasvia pidetään Suomessa vain kuidun vuoksi. Kuituhampun päätuottajamaat ovat Kiina, Pohjois-Korea, Intia ja Venäjä. Euroopassa kuituhampun tuotanto on laajinta Ranskassa (4300 tn vuonna 2004). Suomessa viljeltiin vuonna 2006 kuituhamppua 132 hehtaarilla, öljyhamppua 40 hehtaarilla ja muuta hamppua (esim. paperiteollisuuteen) yhdeksällä hehtaarilla. Hamppua viljellään monia terveysvaikutuksia sisältävää hamppuöljyä varten, mutta EU ei anna tukea yli 0,2 \% kannabinoideja sisältävälle hampulle Sen tähden Suomessa hyvin menestyvän Finolan viljelyä 2007 ei tueta. (Kuitupellava ja -hamppu. 2006; Vuorio H.ym. 2005; Hakuopas. Maa- ja metsätalousministeriö. 2007 Korjaukset hakuoppaaseen. Maa- ja metsätalousministeriö 2006;. Political Science. 2007.)

Hamppua on Pohjois-Savossa viljelty karkeilla kivennäismailla. Hamppu on keväällä sirkkataimivaiheessa erittäin arka alhaisille lämpötiloille. Siemensatotasot ovat vaihdelleet $200-1000 \mathrm{~kg} / \mathrm{ha}$, sato on käytetty osin siemeneksi ja jalostettu osin öljyksi. Hampun viljely on iisalmelaisen viljelijän mielestä ongelmatonta, jos maalajit soveltuvat sille. Hampun viljely on kannattavampana kuin esimerkiksi rypsin.

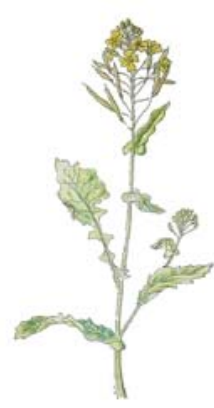

Kuva 3. Rypsi (Brassica rapa

Rypsi (Brassica rapa) kuuluu samaan ristikukkaisten (Brassicaceae) heimoon kuin nauris, turnipsi ja kiinankaali. Rypsi kasvaa 40-100 cm korkeaksi ja kasvutapa on haarova. Suomessa öljykasvien viljely alkoi vasta 1950-luvulla syysrypsin viljelyllä. Rypsin viljelyalue painottuu Lappeenranta-TampereVaasa -linjan eteläpuolelle. Kevätrypsiä viljeltiin koko Suomessa 100600 hehtaarilla vuonna 2006. Suomessa viljellään myös pienillä aloilla syysrypsiä. Sen viljelyä maassamme rajoittaa epävarma talvehtiminen. (Rypsi 2000. Agronet; Rousi A. 1997; Franssila E. (toim.). 2001.)

Rypsiöljy on maailman kolmanneksi käytetyin kasviöljy. Suomessa rypsiöljy on kaikkein eniten käytetty kasviöljy, sitä käytetään myös rehuna ja kiinnostus biopolttoaineisiin on lisännyt sen vaihtoehtoista hyödyntämistä. Rypsirouheen ja -puristeen asema kotimaisena kotieläinten täydennysvalkuaisrehuna on merkittävä. Rypsinsiemenessä on öljyä noin 39-44 \% ja proteiinia 22-24 \%. Öljynpuristuksesta jää jäljelle valkuaisrehua, rypsirouhetta tai -puristetta riippuen menetelmästä. Kuitupitoisuus kummassakin valmisteessa on 11 prosenttia. (Rypsi 2000. Agronet.)

Pohjois-Savossa rypsin tilakohtaiset viljelyalat ovat vaihdelleet 20 - 30 ha. Parhaiten rypsi soveltuu hieta- ja hietamultamaille, mutta herkästi kuorettuvia ja rikkakasvien vaivaamia maita lukuun ottamatta viljely onnistuu lähes kaikilla maalajeilla. Vuoden 2006 sato oli tiloilla keskimääräistä parempi, 1500-2000 kg/ha ja Rautalammilla syysrypsisato oli 2700 kg/ha. Iisalmelainen yrittäjä on jalostanut biodieseliä vuodesta 2005 lähtien. Mukaan otetaan myös esim. ravintoloiden jäteöljyä. Yritys välittää polttoöljyä ulkopuolellekin. Prosessista jäljelle jäävä puristeöljy ja puriste menevät rehutehtaille. Yrityksen tulevaisuus näyttää valoisalta biodieselin kasvavan menekin ansioista. Rypsin viljely vaatii viljelijältä ammattitaitoa. Haastetta viljelylle tuovat etenkin tuholaiset. Rypsin viljely on kannattavampaa kuin viljojen.

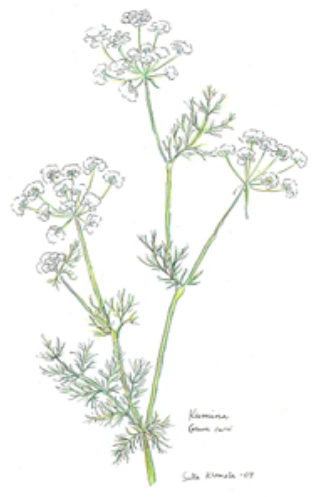

Kuva 4. Kumina (Carum carvi).

Maustekasvina aromipitoisten siementen takia viljeltävä kumina (Carum carvi) on kotoisin Euroopasta ja Länsi-Aasiasta. Elintarvikkeiden lisäksi kuminaa käytetään yhä enemmän non food -tuotteissa. (Hiltunen, S.ym. 1995; Saarnijoki, S. 1974; Kukkonen, I. (toim.) 1987; Galambosi, B. \& Roitti, M. 2006; Saunajoki, O. 2000.)

Kumina on runsashaarainen putkikasvi. Kukkavarsi on n. 80-100 cm korkea, ontto, uurteinen ja kulmikas. Kasvi on kokonaan kalju. Kuminan siemen sisältää pääosin kahdesta monoterpeenistä eli karvonista (50-60 \%) ja limoneenista (n. $40 \%$ ) koostuvia ja haihtuvia öljyjä. Siemenen öljypitoisuus voi vaihdella 2-10 \%. (Saarnijoki, S. 1974; 7; Piippo, S. 2005.)

Kuminan juuristossa on erityisen paljon hyödyllisiä mikrobeja. Nämä hyvät mikrobit pitävät huolta maaperän kunnosta. Ne hajottavat kasvitähteitä, kierrättävät ravintoja ja jopa estävät joidenkin kasvitautien leviämistä. Hyvät 
mikrobit vähentävät muokkauksen, lannoituksen ja torjunta-aineiden tarvetta. (Saarnijoki, S. 1974; 7; Piippo, S. 2005;Aaltonen, T \& Arkko, M. 1999; Kaipainen, S. \& Palojärvi, A. 2006.)

Kuminaa käytetään mausteena, säilytteenä, teenä, lääkkeenä, suuhygieniatuotteina ja hyönteiskarkotteina. Kumina sisältää haihtuvia öljyjä, joilla voidaan torjua erilaisten bakteerien ja sienten kasvua. Kuminassa on myös perunan itämistä ja perunaruttoa torjuvia aineita. (Piippo, S. 2005; Aaltonen, T \& Arkko, M. 1999; Hiltunen, S. ym. 1995; Saunajoki, O. 2000.)

Kuminaa viljellään melkein joka puolella maailmaa. Suurimpia tuotantomaita ovat Alankomaat, Puola, Unkari, Kanada ja USA. Kuminan viljely on lisääntynyt viime vuosikymmenen aikana Pohjoismaista erityisesti Norjassa ja Suomessa. Vuonna 2006 Suomessa kuminaa viljeltiin 22300 hehtaarilla. (Galambosi, B. \& Roitti, M. 2006; 22; Käytössä oleva maatalousmaa vuonna 2005 työvoima- ja elinkeinokeskuksittain. 2005. Maa- ja metsätalousministeriön tietopalvelukeskus.) Kumina viihtyy monenlaisilla kasvualustoilla, parhaiten kivennäismailla, joiden $\mathrm{pH}$ on yli 6. (Saunajoki, O. 2000; Leppälä, J. 2003.) Pohjoissavolaisilla viljelijöillä viljelyalat vaihtelevat 9-30 ha; satotasot ovat olleet $0-1700 \mathrm{~kg} / \mathrm{ha}$. Nollavuodet tarkoittavat erittäin pahoin rikkaruohojen saastuttamaa satoa. Tuottajien mukaan kuminaa on myös helpompi viljellä kuin viljoja, uhkana kuminan viljelyssä ovat tautien ja tuholaisten lisääntyminen viljelyalan laajentuessa. Sen viljely on viime vuosina ollut kannattavaa; suomalaiskuminalla on hieno aromi, mikä on valtti ulkomaanmarkkinoilla.

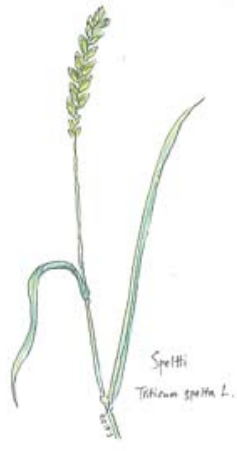

Kuva 5. Speltti (Triticum spelta L)

Speltti (Triticum spelta L.) on yksi vanhimmista viljellyistä viljalajeista, jota kutsutaan myös nimellä muinaisvilja, alkuvehnä ja vaivaisvehnä. Suomessa speltin viljely aloitettiin 90-luvulla, vaikka todisteita sen viljelystä maassamme on löytynyt jo 300-luvulta jKr. Vuonna 2006 speltin viljelylaajuus oli 600 hehtaaria. (Niskanen M. 2001; Hoagland J.T. 1998; Kontturi M.ym. 2000; Larmo K. (toim.) 2006.)

Speltti menestyy parhaiten hyvärakenteisella kivennäismaalla ja talvehtii paremmin rinteillä kuin tasamailla. Suomessa speltin viljely onnistuu parhaiten I ja II-viljelyvyöhykkeillä sekä kolmannen vyöhykkeen parhailla paikoilla. (Niskanen M. 2001; Lounasheimo L. 2001.)

Speltti muistuttaa vehnää monin tavoin. Suurin ero on jyvissä, sillä jyvät eivät ole paljaat, kuten vehnällä, vaan jäävät helpeiden ympäröimiksi. Kukkalehdet muodostavat tähkylän, jonka sisällä on 2-3 jyvää. Tästä syystä speltin jyvät pysyvät kiinni tähkylöissä puitaessakin ja sato on kuorittava ennen käyttöä. Vehnän tavoin spelttiä voidaan käyttää kaikkeen ruuanlaittoon ja leivontaan. Speltin on todettu sisältävän enemmän proteiinia kuin vehnä ja speltin proteiinista on suurempi osa elimistön hyväksikäytettävissä kuin vehnän. (Niskanen M. 2001; Värri M. 2006.)

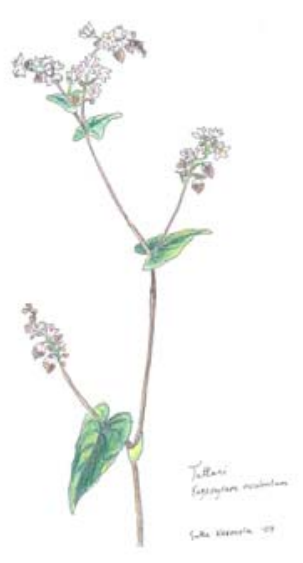

Kuva 6. Tattari (Fagopyrum esculentum)
Pohjoissavolaiset viljelijät ovat kasvattaneet spelttiä 1990-luvun alusta saakka. Pinta-alat ovat vaihdelleet tiloilla 10 hehtaarin paikkeilla. Satoa on saatu 800-3400 kg/ha. Yhdellä tilalla speltin viljely epäonnistui kokonaan ja se lopetettiin kahden vuoden jälkeen. Kokemusten mukaan speltillä ei ole muita riskejä kuin talvehtimisen epäonnistuminen, minkä estämiseksi speltti ei saisi syksyllä kasvaa liikaa. Speltti on erittäin terve kasvi, eivätkä rikkakasvitkaan ole sille ongelma.

Tattari on vanha viljelykasvi, joka kuuluu Polygonaceae-heimoon. Tattareita kasvaa 300 eri lajia, joista ristisiittoista viljatatarta eli tattaria (Fagopyrum esculentum) on viljelty eniten. Viljatatar on kaksisirkkainen kasvi, se ei ole viljakasvi, vaan se kuuluu valeviljoihin eli pleudo-viljoihin. Viljatattarin siemenet ovat gluteenittomia, joten se soveltuu hyvin keliaakikkojen ruoaksi. Kylvösiementen seassa ei saa olla viljan ja retikan siemeniä tai lidunpätkiä. Kiina tuottaa 50 \% maailman tattarista, Venäjä noin 20 \% ja Ukraina 15 \%. Suomessa viljelyala on vaihdellut 500-800 ha välillä, viime vuonna 2006 tattarin viljelyala oli 611 ha. (Montonen, R. \& Kontturi, M. 1997; Hiltunen, S.-ym. 1995.Montonen, R. \& Kontturi, M. 1997; Heikki lä, M. ym. 1992; Keskitalo, M. ym. 2006; Skrypetz, S. 2006.) 
Tattari on 40-140 senttimetrinen, yksivuotinen onttovartinen kasvi. Tattarin viljely onnistuu tavallisen viljatilan koneilla. Sen satotasot voivat vaihdella eri vuosina nollasta jopa 2000 kiloon hehtaarilla. Tattari vaatii lämpöä ja se on erittäin hallanarka kasvi. Syvän juuristonsa ansioista se kestää poutaa varsin hyvin. Se on vaatimaton kasvi maaperän suhteen, sillä se kasvaa happamilla ja vähäravinteisillakin mailla. (Montonen, R. \& Kontturi, M. 1997; Tolppa, R. 2006; Mustonen, E. 2000.)

Pohjoissavolaisilla tiloilla tattaria on viljelty jo 15 vuotta. Viljelyalat vaihtelevat 5-15 hehtaariin ja satotasot ovat olleet $50-1500 \mathrm{~kg} / \mathrm{ha}$. Lapinlahtelainen viljelijä pitää tattaria vaatimattomana kasvina, joka kuitenkin on herkkä kasvuolosuhteille. Hänen mielestään Lapinlahden korkeus alkaa olla pohjoisimpia alueita, missä tattari vielä menestyy. Viljelijä on laskenut, että satotason ollessa 800 $1000 \mathrm{~kg} /$ ha tattarin viljely on kannattavaa hänen tilallansa. Virtasalmelainen viljelijä toteaa, että tattari on vaikein kasvi, jota hän on viljellyt. Hyviä vuosia on ollut vain 3-5 kpl 15 vuoden aikana, tällöin satotaso on noussut yli $1000 \mathrm{~kg} / \mathrm{ha}$.

\section{Yhteenveto ja johtopäätökset}

Tutkimusten mukaan erikoiskasviviljelijät ovat yleensä hieman korkeammin koulutettuja ja pääosin kasvinviljelijöitä. Heidän joukossaan on myös keskimääräistä enemmän luomuviljelijöitä ja niitä, joiden tulot tulevat suurimmaksi osaksi muualta kuin maa- ja metsätaloudesta. Erikoiskasviviljely näyttäisi sopivan viljelijälle, joka on kiinnostunut kokeilemaan uudenlaisia viljelykasveja, etsimään vaihtelua tilalleen ja saamaan tunnettavuutta.

Oppaaseen kootut käytännön kokemukset saattoivat poiketa joissakin tapauksissa teoriatiedosta, sillä kukin soveltaa oppeja omalle tilalleen sopivaksi. Erikoispeltokasviviljelyn lisääntyessä tarvitaan yhä enemmän neuvontaa ja koulutusta näiden kasvien osalta. Aineistosta koottiin sähköinen PDFmuotoinen julkaisu Erikoispeltokasvit - viljelytekniikka. Tarkastelussa camelina, hamppu, rypsi, kumina, speltti ja tattari. -viljelyopas, joka on julkaistu Marjaosaamiskeskuksen sivulla: http://mansikka.netsor.fi/materiaali/erikoispeltokasvit-viljelytekniikka.pdf.

\section{Kirjallisuus}

Aaltonen, T \& Arkko, M. 1999. Yrtit ja villivihannekset. Tampere: Suomen Matkailuliitto Ry.

Bosca I. \& Karus M. 1998. The cultivation of hemp. USA: Hemptech.

Callaway J. 2004. Hempseed as a nutritional resource: An overview. Euphytica 140: Kluwer Academic Publishers. [Viitattu 19.3.2007]. Saatavissa: www.finola.com/HempseedNutrition.pdf

Camelina. 2007. Sopimusviljojen ja öljykasvien viljelyohjeet 2007. [Viitattu 10.3.2007]. Saatavissa: http://192.49.187.88/maatalousryhma/oppaat/Viljelyohjeet_2007.pdf

Franssila E. (toim.). 2001. Öljykasvinviljelijän opas. Maa -ja metsätaloustuottajain Keskusliitto ja Elintarviketeollisuusliiton Öljynpuristamoyhdistys. Lieto: Painoprisma Oy.

Galambosi, B. \& Roitti, M. 2006. Pohjoisessa kasvatettujen yrttien aromisuus. Maa- ja elintarviketalous 84 . Jokioinen: MTT.

Geisler, M. 2006. Camelina Industry Profile. Ag Marketing Resource Center. [Viitattu 14.11.2006]. Saatavissa: www.agmrc.org/agmrc/commodity/grainsoilseeds/camelina/

Heikkilä, M., Lukkarinen, I. \& Valtonen, S. 1992. Tattarin viljely. Maatalouskeskuksen Liiton julkaisuja nro 797. Kasvintuotanto-sarja nro 12. ISBN: Helsinki.

Hiltunen, S., Hedman-Partanen, R. \& Hyytiäinen, T. 1995. Tattari. Kasvintuotanto 2. Rauma: Kirjapaino Oy WestPoint.

Hoagland J.T. 1998. Spelt - What is it? Purity Foods Inc. [Viitattu 27.9.2006]. Saatavissa:

http://www.spelt.com/

Kaipainen, S. \& Palojärvi, A. 2006. Hyvät mikrobit viihtyvät erikoiskasvien juuristossa. Koetoiminta ja käytäntö 4/2006. [Viitattu 2.1.2007]. Saatavissa: www.mtt.fi/koetoiminta/pdf/mtt-kjak-v63n04s14b.pdf

Kangas, A., Laine, A., Niskanen, M., Salo, Y. \& Vuorinen, M. 2006. Kevätrypsi. Peltokasvilajikkeiden viljely -ja käyttöarvon arviointiperusteet. [Viitattu 10.3.2007]. Saatavissa: www.mtt.fi/mtts/pdf/mtts125.pdf Keskitalo, M. 2006. Erikoiskasvit monimuotoisen ja -vaikutteisen kasvinviljelyn voimavara. MTT. [Viitattu 8.3.2007]. Saatavilla: www.mtt.fi/monimuotoisuus/esitelmat/keskitalo.pdf

Keskitalo, M. Yksipuolisesta viljelystä on haittaa. MTT. [Viitattu 10.3.2007]. Saatavissa:

www.mtt.fi/monimuotoisuus/kasvit3.html

Keskitalo, M \& Hakala, K. 2006. Erikoiskasvien juurten salat selville. [Viitattu 10.3.2007]. Saatavissa: www.mtt.fi/koetoiminta/pdf/mtt-kjak-v63n04s14a.pdf

Keskitalo, M., Hannukkala, A. \& Paajanen, L. 2001. Kuminasta biologisesti tehokasta öljyä. Koetoiminta ja käytäntö 3/2001. [Viitattu 16.11.2006]. Saatavissa: www.mtt.fi/koetoiminta/pdf/mtt-kjak-v58n3s08a.pdf 
Kumina. Farmit Website Oy. [Viitattu 10.3.2007]. Saatavissa:

www.farmit.net/farmit/fi/03_kasvinviljely/02_kasvuohjelma/19_kumina/index.jsp

Keskitalo, M., Kontturi, M., Mäki, M., Pihlava, J-M. \& Rantamäki, P. 2006. Tattarista terveellistä popsittavaa. Koetoiminta ja käytäntö 3/2006. [Viitattu 31.12.2006]. Saatavilla: www.mtt.fi/koetoiminta/pdf/mtt-kjakv63n03s02b.pdf

Kontturi M., Salo Y. \& Talvitie H. 2000. Speltti on lupaava ja mielenkiintoinen uusi viljakasvi. Koetoiminta ja käytäntö n:o 3, 57.vuosikerta. Maa- ja elintarviketalouden tutkimuskeskus. [Viitattu 27.9.2006]. Saatavissa: http://www.mtt.fi/koetoiminta/pdf/mtt-kjak-v57n3s02.pdf

Kuitupellava ja -hamppu. 2006. Maa- ja metsätalousministeriö. 7.6.2006. [Viitattu 16.1.2007]. Saatavissa: http://www.mmm.fi/fi/index/etusivu/maatalous/maatalouspolitiikka/markkinajarjestelytjasentehtavat/kuitupellav ajahamppu/luelisaa.htmlKuminan kantakokeet vv. 1990-1991. Yrttitutkimus. Yrttitarha. [Viitattu 10.3.2007]. Saatavissa: www.yrttitarha.com/tutkimus/tutkimus6.html

Kukkonen, I. (toim.) 1987. Suomen suurkasvio 1. Porvoo: WSOY.

Maa- ja metsätalousministeriön tietopalvelukeskus Tike. [Viitattu 9.3.2007]. Saatavissa: www.mmmtike.fi/attachments/.

Larmo K. (toim.) 2006. Tietoa speltistä ja Birkkalan tilasta sekä usein kysyttyjä kysymyksiä. Birkkalan tilan nettisivut. [Viitattu 3.1.2007]. Saatavissa: http://www.birkkala.com/mita.htm

Paavilainen, M. 2005. Terveyttä tattarista. Koelypsy 3/2005.MTT. [Viitattu 11.1.2007].

Saatavissa: https://portal.mtt.fi/portal/page/portal/MTT/JULKAISUT/KOELYPSY/LEHDEN_NUMEROT/ 1_2005/7.html

Lehtonen, S. 2006. Suomi on camelinatutkimuksen kärkimaa. Koetoiminta ja käytäntö 63(4). [Viitattu 28.12.2006]. Saatavissa: http://www.mtt.fi/koetoiminta/pdf/mtt-kjak-v63n04s09a.pdf

Leppälä, J. 2003 Kuminanviljelyopas. Trans Farm Oy.

Montonen, R. \& Kontturi, M. 1997. Tattarin viljelyopas. Maatalouden tutkimuskeskuksen julkaisuja nro 14. [Viitattu 31.12.2006]. Saatavilla: www.mtt.fi/asarja/pdf/asarja14.pdf

Muuttomaa, E .2001. Camelina - uusvanha öljykasvi jälleen viljelyssä. Teho 5/2001.

Niskanen M. 2001. Spelt-viljan viljelyopas. Ylistaron painopalvelu.

Pahkala K. \& Virkajärvi P. 2004. Hampun viljelytutkimukset. ”Hampussa on toivoa”-seminaari, 23.2.2004, Suonenjoki.

Palojärvi, A. Maaperän ja ritsosfäärin mikrobiyhteisön monimuotoisuus. MTT. [Viitattu 17.3.2007]. Saatavissa: http://tripunix.mtt.fi/cgi-bin/thw/?\$\%7BBASE\%7D=wwwtuike\&\$\%7BHTML\%7D=docu\&\$\%7BTHWID S\%7D=3.2/26247\&\$\%7BTHWURLSAVE\%7D=2/26247

Partala A. 2007. Speltti tilastoissa. [Sähköpostiviesti]. anneli.partala@mmmtike.fi. 4.1.2007. [Viitattu 4.1. 2007].

Piippo, S. 2005. Luonnonyrtit, villivihannekset ja marjat. Porvoo: WSOY.

Political Science. 2007. News and Info. Finola Ky. [Viitattu 23.3.2007]. Saatavissa: http://www.finola.com/ Pölkki M. 2002. Hampun öljystä ja proteiinista terveysvaikutteisia elintarvikkeita. Helsingin Sanomat 9.8.2002. Rousi A. 1997. Auringonkukasta viiniköynnökseen. Porvoo-Helsinki-Juva: WSOY.

Rypsi 2000. Agronet -sivusto. [Viitattu 10.3.2007]. Saatavissa: http://www.agronet.fi/rypsi2000/yleistietoa.htm Saarnijoki, S. 1974. Maustekasvien viljelyhistoriaa 1900-luvun alkuun. Helsingin yliopisto. Puutarhatieteen Pro Gradu -tutkielma.

Saunajoki, O. 2000. Kumina Pohjois-Satakunnan viljelyolosuhteissa. Työtehoseuran maataloustiedote. 9:2000. Skrypetz, S. 2006. Buckwheat: Situation and Outlook. Agriculture and Agri-Food Canada. [Viitattu 4.1.2007]. Saatavilla: www.agr.gc.ca/mad-dam/index_e.php?s1=pubs\&s2=bi\&s3=php\&page=bulletin_18_18_1_2005-1007

Tolppa, R. 2006. Gluteenittoman tattarin viljely vaatii huolellisuutta. ProAgria Pirkanmaa. [Viitattu 22.3.2007]. Saatavissa: www.agronet.fi/mkl/06/tattari.html

Venäläinen, E., Valkonen, E. \& Vajala J. 2006. Camelinapuriste sopii broilereiden rehuun. Koetoiminta ja käytäntö 63 (4). [Viitattu 28.12.2006] .Saatavissa: http://www.mtt.fi/koetoiminta/pdf/mtt-kjak-v63n04s11b.pdf Virkajärvi P. \& Kangas A. 2005. Öljyhampun viljelytekniikka. MTT Pohjois-Savon tutkimusasema ja MTT Etelä-Pohjanmaan tutkimusasema. Vuori, S. 2005. Camelinan sadonkorjuu onnistui odotetusti. Maatilan Pellervo 10/2005.

Williams, W. 2005. MSU Researchers Say New Crop Could Produce Affordable Biodiesel. EF Multimedia. [Viitattu 15.11.2006]. Saatavissa: www.harvestcleanenergy.org/enews/enews_0605/enews_0605_Camelina.htm Vuorio, H., Soini, K. \& Ikonen, A. 2005. Kenestä erikoiskasviviljelijäksi. MTT:n selvityksiä 102. MTT: Jokioinen.

Värri, M. 2006. Speltti voittaa viljelyalaa. Käytännön Maamies 15/2006. 